\title{
DIAGNÓSTICO SOCIOAMBIENTAL E IMPACTOS DO TURISMO NA VILA DE ENCANTADAS, ILHA DO MEL'1.
}

\begin{abstract}
Daniel Hauer Queiroz Telles ${ }^{2}$
Este resumo refere-se à pesquisa em andamento, titulada provisoriamente "diagnóstico socioambiental e impactos do turismo na vila de Encantadas, ilha do Mel". O presente trabalho tem como justificativa avaliar a evolução das questões sociais e ambientais dentro da devida área de estudo. Objetiva compreender as problemáticas socioambientais que existem dentro desta vila. Estas problemáticas possuem relação têmporo-espacial com a ascensão da atividade turística no local ao longo das últimas décadas. O processo de comercialização do solo relacionado à expansão da ocupação e o surgimento de novos atores sociais associado à aculturação da população tradicional, consistem em razões primárias da eminência destas problemáticas. Metodologicamente, esta pesquisa baseouse em revisão bibliográfica de assuntos e conceitos que oferecem suporte teórico para a compreensão geográfica da dinâmica espacial. Além da revisão de materiais, dados e trabalhos relacionados à área de estudo, estão também sendo realizadas entrevistas direcionadas a duas fontes de informação: a população local, no intuito de associar a opinião pública ao objeto de estudo e o poder público, a fim de obterem perspectivas de ação nos níveis de reordenamento do território e medidas mitigadoras para resolução de conflitos de uso do solo. Como perspectiva final pretende-se ligar as questões sociais, a gestão local e a ocorrência do turismo, e analisar de que maneira tais esferas convergem, para então estimular a implantação de um plano de recuperação ambiental.
\end{abstract}

PALAVRAS-CHAVE: vila de Encantadas; atividade turística; problemáticas socioambientais.

\footnotetext{
${ }^{1}$ Orientador: Prof. Dr. Everton Passos

${ }^{2}$ Mestrando em Geografia (UFPR) - e-mail: dhqt_geog@yahoo.com.br
} 